\title{
o cigarro em propaganda na revista Ilustração Brasileira: uma experiência estética
}

\section{LARA LOPES}

\section{Resumo}

O objetivo deste trabalho é compreender a construção das propagandas de cigarro publicadas na revista Ilustração Brasileira entre 1937 e 1945. Essas propagandas são compostas de reproduções de fotografias de atrizes segurando um cigarro e textos que associam o produto à elegância e sensualidade. Ainda que o cigarro ganhe destaque, tanto nas imagens quanto nos textos, não há menção nessas páginas de marcas ou anunciantes - a propaganda é camuflada no conteúdo da revista se integrando a publicação como parte dela. Sendo assim, considerando que os principais elementos simbólicos das propagandas são o cigarro, o cinema e a mulher, pretende-se

Palavras-chave: Revista Ilustração Brasileira, propaganda, cigarro analisar como estes elementos foram integrados tanto nas imagens quanto nos textos, a fim de transformar o ato de fumar em uma experiência estética. 


\section{The cigarette advertising in Ilustração Brasileira magazine: an aesthetic experience}

\section{LARA LOPES}

\begin{abstract}
The aim of this work is to understand the construction of cigarette advertisements published on Ilustração Brasileira magazine between 1937 and 1945. These advertisements show reproductions of photographs of actresses holding a cigarette and texts that associate the product with elegance and sensuality. Although the cigarette was a highlight, both in pictures and texts, there is no mention in these pages about trademarks or advertisers, the advertising is camouflaged in the magazine's content integrating the publication as part of it. Therefore, considering that the main symbolic elements of the advertisements are the cigarette, the cinema, and the woman, we intend to analyze how these were integrated both in images and texts in order to transform the act of smoking into an aesthetic experience.
\end{abstract}

Keywords:

Ilustração Brasileira magazine, advertising, cigarette 


\section{El cigarrillo en la publicidad de la revista Ilustração Brasileira. una experiencia estética}

\section{LARA LOPES}

\section{Resumen}

El objetivos de este trabajo es comprender la construcción de las propagandas de cigarrillo publicadas en la revista Ilustração Brasileira entre los años 1937 y 1945. Tales propagandas son compuestas por reproducciones de fotografías de actrices sosteniendo un cigarrillo y textos que asocian el producto a la elegancia y la sensualidad. Aunque el cigarrillo sea destacado, tanto en las imágenes como en los textos, no se hace mención de marcas o anunciantes en esas páginas - la publicidad es camuflada en el contenido de la revista y se integra a la publicación como parte de ella. De ese modo, considerando que los principales elementos simbólicos de las propagandas son el cigarrillo, el cine y la mujer, se

Palabras clave: Revista Ilustração Brasileira, propaganda, cigarrillo pretende analizar cómo dichos tópicos fueron integrados tanto en las imágenes como en los textos con la finalidad de transformar el acto de fumar en una experiencia estética. 
$\mathrm{N}$ a edição de dezembro de 1937 foi publicada pela primeira vez na revista Ilustração Brasileira uma página singular que viria a ser veiculada de forma constante até a edição de abril de 1945 . Ainda que não fosse uma seção da revista com título definido, e também não constasse no editorial do periódico, essa página singular se repetiu durante oito anos em quase todos os exemplares publicados. À primeira vista, a página causa estranheza em quem folheia a revista, e essa é uma das razões pela qual a identifico como singular. O termo em uso neste trabalho pode parecer ambíguo, pois ainda que essas propagandas pareçam singulares ao público de hoje, elas podem não ter sido entendidas de tal forma no contexto em que foram produzidas. No entanto, ao compreender o perfil editorial da revista em que foram veiculadas essas páginas, percebemos que elas também se tornavam singulares dentro da própria publicação, uma vez que esta não trazia em seu conteúdo matérias relacionadas ao cinema.

Para analisar tais propagandas foi importante identificar os principais elementos que compunham as mesmas e compreender como eles foram integrados tanto nas imagens quanto nos textos para produzirem significados quando lido/ vistos pelos leitores. Nesse sentido é importante ressaltar que as imagens são documentos privilegiados dentro deste estudo e não serão tratadas como meras ilustrações. Segundo Luciene Lehmkuhl (2010, p. 54) alguns historiadores, ao contrário do que propunha a história tradicional positivista que sobrepunha os documentos escritos aos visuais, se propuseram a fazer história com documentos visuais. As imagens nem sempre são valorizadas como fonte de pesquisa pelos historiadores.

Para o historiador, deparar-se com imagens em meio aos documentos escolhidos para a elaboração de sua narrativa é acontecimento muitas vezes carregado de medos e descon- 
fianças, seguido do abandono das imagens ou então da opção por utilizá-las de maneira meramente ilustrativa, em capas, folhas de rosto, entradas de capítulos, abertura de apresentações e explanações de conteúdos. Ao fazer tais escolhas, o historiador perde a oportunidade de sondar novos olhares, de penetrar em universos outros, anteriormente não explorados (LEHMKUHL, 2010, p. 55).

A imagem, assim como outros tipos de documentos, é uma construção social. Ela assume funções e sentidos diferentes de acordo com o contexto em que é veiculada. "Nenhuma imagem é, então 'verdadeira' ou 'falsa', é apenas adequada a uma cultura ou momento para expressar significados" (LEHMKUHL, 2010, p. 58).

Na edição de 1937 a revista traz uma grande fotografia em preto e branco que ocupa quase metade da página (Figura 1). Nela, uma mulher com olhar longínquo segura um cigarro que ganha destaque por estar em frente ao seu rosto, no primeiro plano da imagem. Logo abaixo, o título Os gestos em épocas distinctas e o texto salientando que em cada época as mulheres utilizaram-se de gestos e poses para realçar sua beleza. E adverte que, "nos nossos dias, o gesto característico é esse de saber levar um delicioso cigarro aos lábios, sorver com delícia o fumo suave, e sopral-o [sic], com elegância" (ILUSTRAÇÃO BRASILEIRA, 1937, p. 51). Assim, de acordo com o texto, que também nos induz a ler a imagem, a mulher que se fazia bela era aquela que sabia utilizar o cigarro, explorar os gestos de segurá-lo, sorver e soprar sua fumaça.

Ainda que o texto e a imagem tragam o cigarro como elemento fundamental para a construção da página, em nenhum momento o texto se refere a marcas específicas, apenas sugere o consumo do produto em si. No entanto, não podemos afirmar que os leitores não tinham consciência de que se tratava de uma propaganda comercial. É importante pensarmos para este estudo que existem várias formas de propaganda, elas podem ser tanto comerciais como não comerciais.

Assim, ao tratar da propaganda comercial, podemos distingui-la em várias modalidades, sendo estas a propaganda de prestígio, em que o anunciante dissemina não um produto, mas o próprio nome da empresa ou sua imagem; a propaganda industrial, em que a empresa anuncia seus produtos a outras empresas; os anúncios de exibição, aqueles que são postos em destaque em jornais e revistas a fim de chamar a 


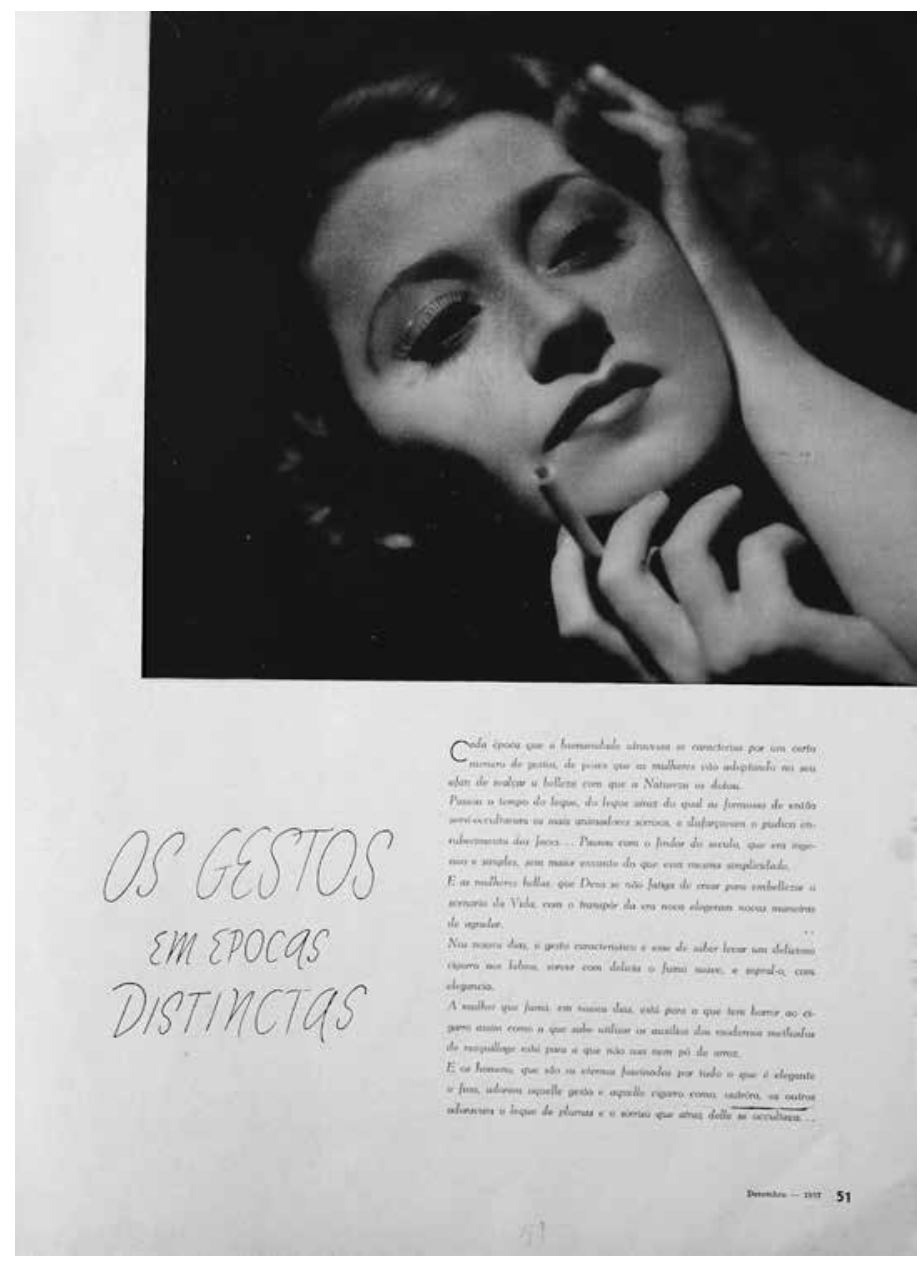

atenção dos leitores, ou seja, dos consumidores; os classificados, inseridos em páginas especiais, cujo anúncio é feito geralmente por pequenas empresas ou por um cidadão que redige o próprio texto, diferenciando-se dessa forma dos anúncios de exibição, que são feitos por publicitários e agências especializadas (VESTERGAARD; SCHRODER, 2004, p. 4). Incluo nessa perspectiva ainda outra forma de se fazer propaganda: a propaganda indireta, aquela que não aparece de forma explícita e não utiliza, para promover um determinado produto, a marca do anunciante. A propaganda não é feita sempre na forma de um anúncio tradicional, ela pode também aparecer camuflada em editoriais, reportagens, filmes, livros. 
Segundo Vestergaard e Schroder (2004, p. 93), essa é uma das maneiras usadas para que o anúncio chame atenção, "fingindo que não é anúncio". Esse método é interessante principalmente quando pensamos no tipo de publicação em que a propaganda foi veiculada, uma revista ilustrada, em que o interesse do público que consome o impresso possivelmente está nos artigos, nas imagens, dicas e curiosidades que são publicados nesse meio. Essa se torna, então, uma estratégia da propaganda comercial para se fazer notar em meio à diversidade da publicação, integrando-se ao conjunto dela. Foi simulando-se como parte da revista que as propagandas de cigarros foram divulgadas dentro da Ilustração Brasileira.

\section{Um olhar sobre a revista Ilustração Brasileira}

Fundada por Luiz Bartholomeu de Souza e Silva e Antônio Azeredo, a revista Ilustração Brasileira teve sua primeira edição publicada no dia $1^{\circ}$ de junho de 1909 . Editada pela Sociedade Anônima O Malho, também responsável por outras revistas de sucesso como O Malho, Tico-Tico, Para Todos, Leitura Para Todos, Moda e Bordado, Arte de Bordar, Cinearte, Annuario das Senhoras, Almanaque d'o Tico Tico, Almanaque d'O Malho, além de álbuns, coleções e livros, a Ilustração Brasileira foi um dos periódicos que obtiveram sucesso em meio a diversas outras publicações do período.

Circulou entre os anos de 1909 e 1958, mas não de forma ininterrupta, passou por três fases de publicação. A primeira corresponde aos anos entre 1909 e 1915; a segunda, entre 1920 e 1930; e a terceira se inicia em 1935 e termina em 1958, ano em que a revista finaliza suas atividades. Essas fases não corresponderam apenas a pausas na editoração, mas também a mudanças no próprio projeto gráfico da revista.

Desde a sua primeira edição, a Ilustração Brasileira publicou, com primor técnico, fotografias, ilustrações e reproduções de obras de arte. A materialidade da revista também evidenciava essa preocupação estética, era impressa em grande formato $(36 \times 27 \mathrm{~cm})$ e confeccionada em papel couchê, mais apropriado para a reprodução de imagens com qualidade (CARNEIRO, 2010, p.53). Suas capas eram feitas em papel cartão, em quatro cores, com destaque ainda para o relevo na impressão, sendo assim considerada uma revista de luxo para a época.

A revista publicava uma variedade de temas, que vão de crônicas, poemas, ilustrações, fotorreportagens, artes, letras, doutrinação política e religiosa, até a exaltação de persona- 
gens históricos, economia, crítica literária e de artes, moda, festas, sociedade e acontecimentos, tanto nacionais quanto internacionais. Todos esses conteúdos eram inseridos dentro de suas várias seções, sendo as mais recorrentes e também cujos títulos eram escolhidos para compor o sumário: De mez a mez, Instantâneos de todo o mundo, Artes e artistas, $O$ Rio de hoje e de há 30 annos, Mundanismo e Trichromias.

Pensar o conteúdo que compunha a revista e seu perfil editorial é de extrema importância para compreendermos também quem era o público-alvo do periódico, ou seja, seu público leitor. Tânia Regina de Luca destaca a importância da natureza do conteúdo no sentido de se identificar o possível público desses meios. Para ela, "a ênfase em certos temas, a linguagem e natureza do conteúdo tampouco se dissociam do público que o jornal ou revista pretende atingir" (LUCA, 2008, p. 140). Pensar o conteúdo da Ilustração Brasileira é de grande relevância também para se identificar o público da revista, se compreendermos que eles não estão dissociados. A Ilustração Brasileira, assim como muitos outros periódicos, não trazia em suas páginas nenhuma seção com cartas de leitores. Não cultivava, dessa forma, uma seção de diálogo direto com o público. Entretanto, podemos identificar a quem se destinava a revista com base em seu próprio perfil editorial. Os temas das matérias da revista também são relevantes nesse aspecto. Com caráter ufanista, geralmente traziam exaltações às figuras políticas do Brasil, à indústria e às riquezas do país. Publicava constantemente poemas e matérias sobre as artes plásticas, matérias essas provavelmente destinadas a um público letrado que consistia em uma pequena parcela da população no período. Estima-se que, na década de 1930, por exemplo, cerca de $75 \%$ da população era analfabeta (DUTRA, 2013, p. 230).

\section{$O$ cigarro em propaganda na revista Ilustração Brasileira}

As propagandas de cigarro foram amplamente difundidas na revista Ilustração Brasileira, principalmente em sua terceira fase (1935-1958), período em que houve maior disseminação dos cigarros industrializados, o que de forma alguma significa que não houve propagandas em suas outras fases. No entanto, é em sua terceira fase que a Ilustração Brasileira adotou a propaganda indireta para propagar o consumo dos cigarros. Entre dezembro de 1937 e abril de 1945 foram publicadas na revista 73 propagandas com esta característica. Trata-se 
de um número bastante expressivo, principalmente quando comparamos com a quantidade de anúncios de cigarros com linguagem tradicional (aquelas que apresentam o nome do anunciante) que foram veiculados na revista no mesmo período, apenas 10 anúncios. Outra singularidade se dá na posição que essas propagandas eram impressas dentro da revista, publicadas na maioria dos casos entre as páginas de números 38 e 41. Enquanto as propagandas tradicionais eram destacadas do conteúdo da Ilustração Brasileira ocupando as primeiras e as últimas páginas do periódico, as propagandas indiretas de cigarros eram publicadas entre as seções da revista.

A propaganda comercial tem como função mostrar o produto de forma esteticamente agradável, incitando o desejo do possível consumidor. Para isto utiliza, com frequência, elementos verbais e textuais para compor a mensagem. Podemos perceber esses aspectos nas propagandas indiretas de cigarro que eram compostas de imagens fotográficas e textos associados entre si. É relevante considerar a importância dos elementos fundamentais que foram utilizados para compor essas páginas. Considero que esses elementos são o cigarro industrializado, o cinema e a mulher. Para a análise feita nesse trabalho foi imprescindível pensar cada um desses elementos para compreender como eles foram integrados à página para produzirem significados quando lidos/vistos pelos leitores.

O cigarro é mais do que um produto industrializado nas propagandas, ele apresenta múltiplos significados dentro da Ilustração Brasileira. Segundo Richard Klein (1997, p. 49) os cigarros são signos ambíguos, difíceis de interpretar devido a diversidade de significados e intenções que eles representam. É nesse sentido que operam as propagandas, elas constroem mensagens nas quais apresentam o produto agregado de valores simbólicos. Ela tem que "convencer o leitor de que o produto vai satisfazer alguma necessidade que até então não fora sentida" (VESTERGAARD; SCHRODER, 2004, p. 71).

Dentro das propagandas da Ilustração Brasileira os cigarros aparecem de duas formas: como acessório de elegância e sensualidade e como um amigo nas horas de solidão. Em ambos os casos, vemos que a ideia predominante é a de que o produto é sinônimo de distinção social e bom gosto. Na edição publicada em julho de 1938, a propaganda indireta de cigarros faz clara associação entre cigarro e elegância (Figura 2), sendo esse inclusive o próprio título da página. 


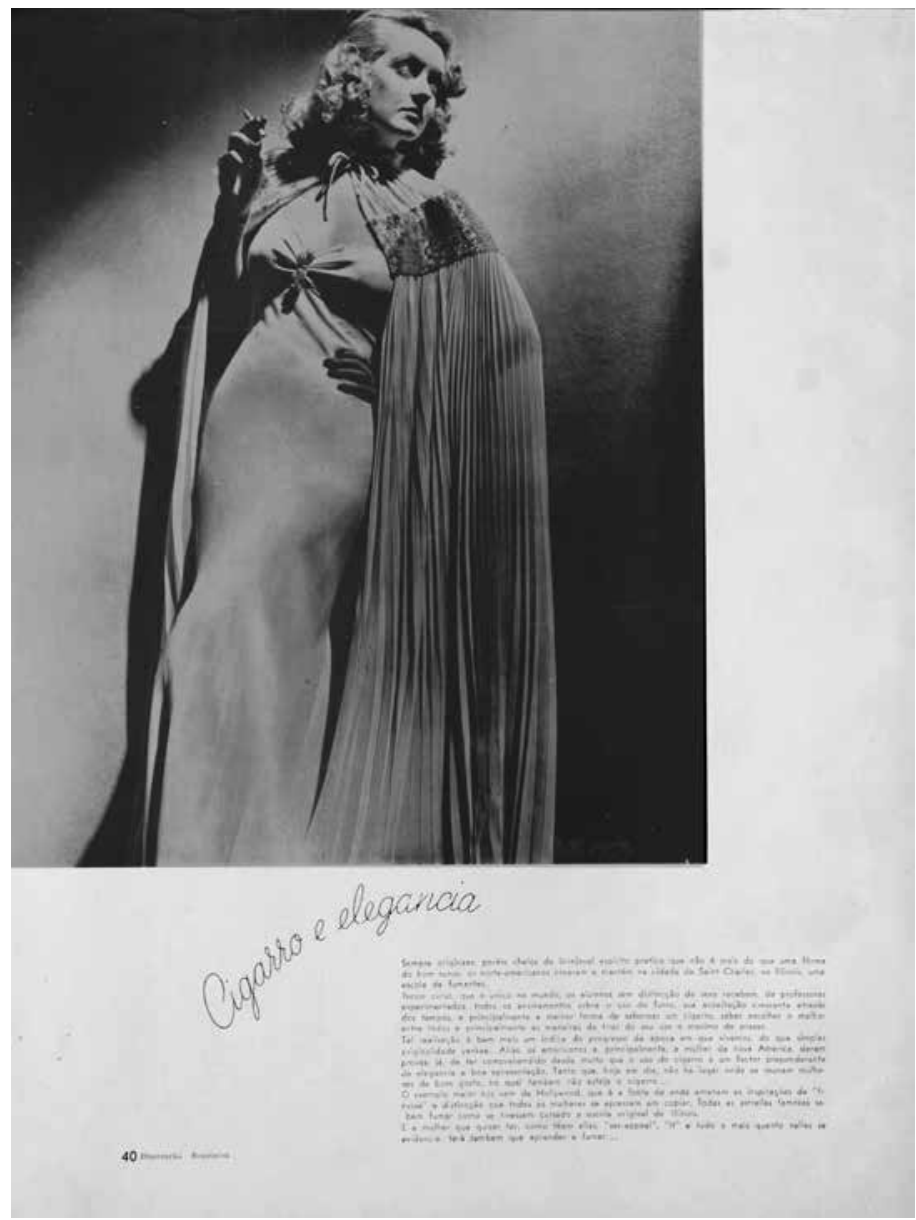

Assim, como a maioria das páginas em estudo, essa propaganda é composta de uma fotografia em preto e branco em grande formato e um texto que a acompanha. Nessa imagem vemos uma mulher com vestido longo, que ressalta as formas de seu corpo, e em uma das mãos segura um cigarro próximo ao rosto. O texto intitulado Cigarro e elegância não diz quem é a mulher, mas pelas características físicas acredito tratar-se de Bette Davis, famosa atriz norte-americana que teve uma longa carreira em Hollywood. O texto da propaganda fala de uma suposta escola nos Estados Unidos dedicada aos ensinamentos do uso do fumo. Segundo esse texto, não seria esta uma originalidade norte-americana, mas sim um índice de progresso desta sociedade. Destaca ainda o papel da mulher estadunidense que já teria compreendido o valor do uso do 
cigarro para lhes garantir elegância, fator que pode ser percebido principalmente entre as atrizes de Hollywood (ILUSTRAÇÃO BRASILEIRA, 1938, p. 40).

O exemplo maior nos vem de Hollywood, que é fonte e onde emanam as inspirações de "finesse" e distincção que todas as mulheres se apressam em copiar. Todas as estrellas famosas sabem fumar como se tivessem cursado a escola original de Illinois.

E a mulher que quizer ter, como têem ellas, "sex-appel", "it" e tudo mais quanto nelas se evidencie, terá também de aprender a fumar... (ILUSTRAÇÃO BRASILEIRA, 1938, p.40).

Para a propaganda fumar é sinônimo de distinção e de elegância, qualidades atribuídas às atrizes de Hollywood. E a mulher que também quiser ter essas qualidades deve, assim como as estrelas, aprender a fumar. A imagem da atriz hollywoodiana dentro da página segurando o cigarro é então essencial para a construção da ideia pretendida pela propaganda. Devido ao destaque que tem dentro da página, a fotografia se torna o principal elemento da mensagem, enquanto o texto parece vir como um complemento, uma sugestão de leitura da imagem.

Roland Barthes observou esse tipo de prática ao pensar a relação de imagens e textos em periódicos, podemos estender as observações do autor também às propagandas. Para eleé comum ver-se uma inversão, em que a imagem já não ilustra a palavra. É a palavra que passa a ilustrar a imagem (BARTHES, 2009, p. 21).

Sendo assim, a disposição dos dois elementos na composição da página, texto e imagem, não pode ser considerada como uma montagem sem intencionalidades. Em primeiro lugar, é preciso refletir sobre o meio em que foi inserida a propaganda: uma revista ilustrada. Os sentidos de uma imagem estão ligados a vários fatores e um deles é o seu suporte, o qual pode determinar também os seus usos. Por tratar-se de um impresso a imagem da propaganda é uma reprodução técnica. É preciso considerar que "uma fotografia de imprensa é um objeto trabalhado, escolhido, composto, construído, tratado segundo normas profissionais, estéticas ou ideológicas, que são tantos outros fatores de conotação" (BARTHES, 2009, p. 15).

A Ilustração Brasileira, a fim de dar evidência ao cigarro em suas propagandas, empregou diversos recursos, tanto visuais quanto textuais. O cigarro aparece sempre em destaque dentro dos textos que compõem a propaganda, no entanto, outra estratégia muito utilizada é a de manipular a imagem para ressaltar a fumaça que sai do cigarro. Através da pesquisa 
pude observar que esse recurso foi utilizado em 21 das 73 propagandas indiretas publicadas entre 1937 e 1945.

Manipulações em uma fotografia podem ser feitas desde o momento em que ela é concebida pelo fotógrafo.

Tais manipulações/interpretações, que muitas vezes se confundem em uma só atitude, envolvem: o fotógrafo, que registra - e cria - o tema; o cliente ou contratante, que lhe confia a missão de retratar ou documentar; a casa publicadora (se é que a imagem foi veiculada, seja na época de sua produção, seja posteriormente em qualquer época), que a utiliza segundo determinada orientação editorial; os diferentes receptores (contemporâneos à sua produção, ou que tomaram contato com ela posteriormente à sua realização, que a veem - seja em sua forma original, seja impressa- e reagem de formas totalmente diversas- emocionalmente ou indiferentemente- na medida em que tenham ou não alguma espécie de vínculo com o assunto registrado, na medida em que reconheçam ou não aquilo que veem (em função dos repertórios culturais individuais), na medida em que encarem com ou sem preconceitos o que veem ( em função das posturas ideológicas de cada um) (KOSSOY, 2001, p. 118).

Sendo assim, tanto a imagem quanto a recepção dela é uma construção social. As manipulações dentro das fotografias são formas de conferir diferentes significados a elas e, no caso das propagandas, visam dar o destaque necessário para que ao se olhar para a imagem o cigarro não passe despercebido. Conferem-lhe importância e destaque tanto nas fotografias quanto nos textos que as acompanhava.

\section{O cinema dentro das propagandas de cigarro}

Compreender quais as possíveis razões que levaram a revista Ilustração Brasileira a optar pela publicação de fotografias de atrizes em suas propagandas de cigarro é crucial para esse trabalho. Por que a escolha de atrizes, principalmente hollywoodianas, e não outras mulheres? O que representavam as atrizes e o cinema hollywoodiano nas décadas de $1930-1940$ ?

O cinema é o ponto de partida para entendermos essas questões. O período compreendido entre as décadas de 1920 e 1950 é considerado a Era de Ouro de Hollywood, quando o cinema detinha o monopólio do entretenimento. Também foi chamada de Era dos grandes estúdios, quando estúdios como Metro-Goldwyn Mayer, Columbia, Paramount, United Artists, 
RKO dentre outros assumiram o caráter de grandes estruturas empresariais conservadas até por volta de 1950, quando o cinema perde espaço para a televisão.

Um dos maiores triunfos da indústria cinematográfica foi a criação do Star System, mecanismo em que eram fabricadas as estrelas do cinema. Apoiando-se no sucesso dos atores e atrizes, a indústria utilizou dele para ampliar seus negócios. Passou ela mesma a produzir suas estrelas por meio de mecanismos como a publicidade, as revistas especializadas e as colunas de fofoca de jornais. Por esses mecanismos e nesses meios eram criadas imagens que incitavam fascínio através da aparência de elegância e glamour.

Nesse sentido, o culto às estrelas vai além do público do cinema, pois os signos cinematográficos são difundidos também por outros meios de comunicação através de notícias, editoriais de moda, cartazes dos filmes e de propagandas. Esse circuito amplia o público que têm acesso às representações, ultrapassando os frequentadores das salas de exibição e atingindo aqueles que liam as revistas especializadas em cinema e também as revistas ilustradas.

A utilização das imagens de atrizes, tanto pela indústria cinematográfica quanto pela imprensa, era interessante para criar o processo de projeção/identificação entre as atrizes e o público. Esse processo se tornou possível devido à produção de uma imagem de glamour criada para essas mulheres, tratando-as como estrelas. Segundo John Berger o glamour é uma invenção moderna, é o que torna um indivíduo invejável. "O estado de ser invejado é o que constitui o glamour" (BERGER, 1999, p. 133). Dessa forma, o público não só se identificava com as estrelas, como queria se parecer com elas, e a propaganda explorava esse desejo mostrando que o glamour era consequência da aquisição do produto usado pelas atrizes.

As imagens das atrizes hollywoodianas publicadas na revista conferem um ar de sensualidade e elegância. Propriedades características da estética fotográfica da Era de Ouro de Hollywood em que predominavam elementos como o jogo de sombra e luz. O contraste entre claros e escuros foi fundamental para criar certa dramatização a essas imagens. A ausência ou pouca relevância dada ao cenário é outra particularidade para destacar as estrelas que deveriam ser as únicas a chamar atenção na imagem.

A propaganda evidencia as atrizes enquanto modelo de conduta, incentivando que os leitores percebam que suas "belas atitudes" são o que há de mais atual no período. Além de associá-las a adjetivos como beleza, sensualidade e belas ati- 
tudes, a propaganda mostra que mulheres comuns poderiam se assemelhar às atrizes copiando-as. Várias mulheres tiveram suas fotografias utilizadas nas propagandas indiretas da revista Ilustração Brasileira. Considerando aquelas cujos nomes foram divulgados (houve propagandas em que não apareceu o nome da atriz) nas páginas, foram publicadas fotografias de 32 artistas. É importante ressaltar ainda que algumas delas apareceram em mais de uma propaganda. Trata-se de nomes de sucesso no período como Bette Davis, Isa Miranda, Joan Bennet, Claudette Colbert, Ann Sheridan, Lupe Velez, Carmen Miranda, Loretta Young dentre outras.

Muitas estratégias foram utilizadas para potencializar o processo de identificação entre público e atriz. Uma dessas foi a utilização da técnica do close-up. Segundo Laura Mulvey (1996, p. 124) o close-up, especificamente quando utilizado nas imagens das estrelas femininas, está ligado a fascinação com a beleza dessas mulheres. A Ilustração Brasileira utilizou de fotografias que traziam as atrizes em close-up para compor sua página destinada à propaganda de cigarro. O close-up tem efeito de aproximação psíquica, transformando o sentido de distanciamento em intimidade entre a imagem e o espectador (AUMONT, 1993, p.141).

Na edição de janeiro de 1939, o periódico publicou uma propaganda de cigarros composta por uma fotografia grande ocupando metade da página e logo abaixo o texto que tende a explicar o que os editores gostariam que fossem assimilados através da imagem (Figura 3). Isa Miranda é o destaque desta fotografia, imagem esta que se enquadra dentro das características próprias dos instantâneos hollywoodianos no período. Aparentemente encostada em uma poltrona, a atriz ostenta um cigarro em uma das mãos enquanto permanece com um olhar longínquo. Podemos notar claramente a fumaça que sai do cigarro, possivelmente uma manipulação feita na imagem para chamar a atenção do leitor para o produto. O texto intitulado Evocação vem a esclarecer, trata-se de um momento em que após as agitações de uma vida tumultuada, o silêncio se impõe. É neste momento que ela evoca a melhor companhia: o cigarro.

$\mathrm{O}$ texto sugere que a atriz foi flagrada em um momento íntimo pelo fotógrafo, enquanto fuma envolta em seus pensamentos. Além do close-up, outra estratégia utilizada pela revista para aproximar o leitor das estrelas era o flagrante. Em muitos casos, as propagandas se referiam às fotografias como sendo resultado de um momento de intimidade da atriz, ainda que a imagem seja nitidamente posada. 


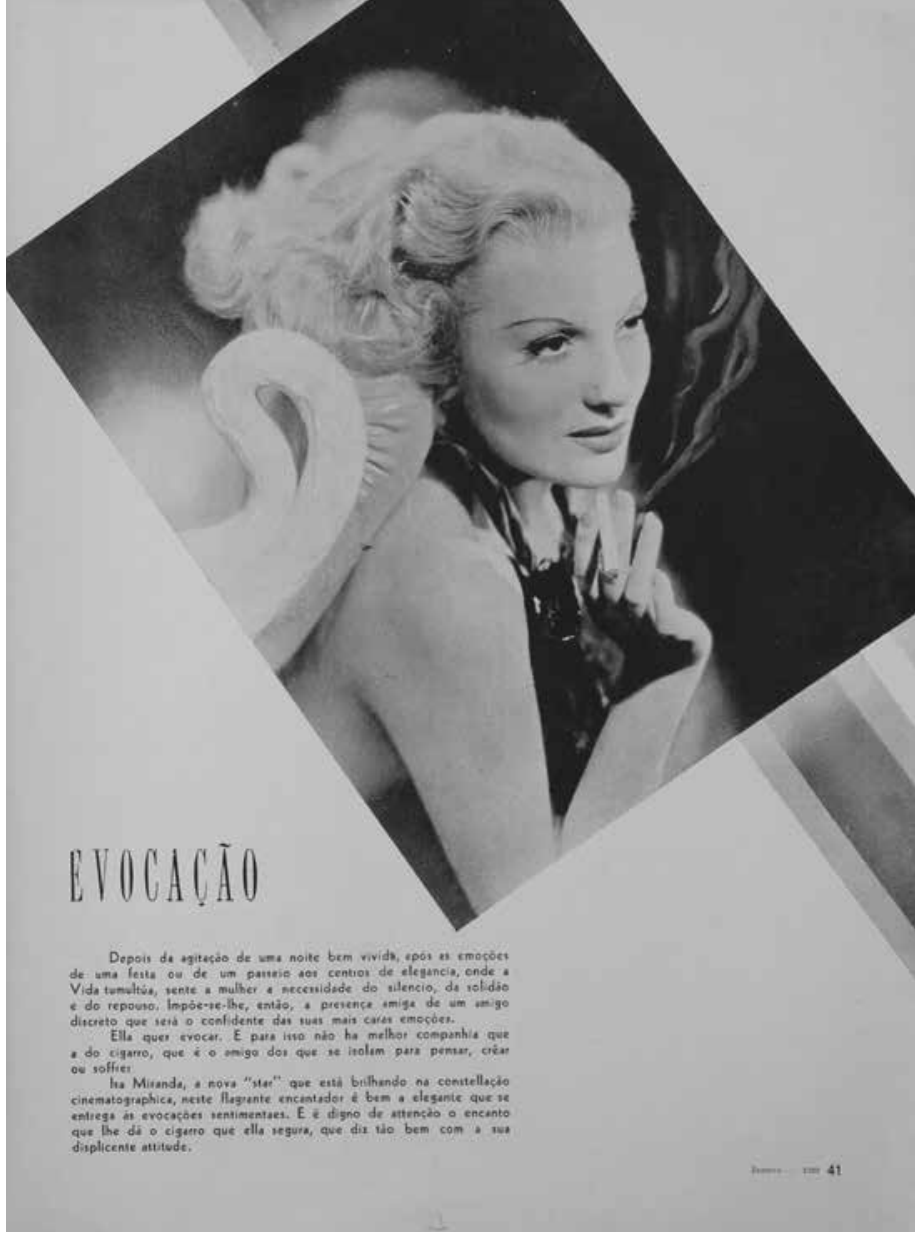

\section{O cigarro e a teatralização dos gestos}

Gestos, atitudes, hábitos são palavras muito comuns dentro das propagandas de cigarro da revista. Segundo a publicação, haveria gestos próprios à mulher que a distinguiria tornando-a moderna, elegante e sensual. A edição de março de 1939 contém uma propaganda que evidencia tais atitudes. Intitulada Gente de hoje (ILUSTRAÇÃO BRASILEIRA, 1939, p. 40) é composta de uma imagem em tamanho grande e de um texto (Figura 4).

A imagem centralizada está disposta de forma inclinada, o que imprime dinamismo à página, assim como o texto também inclinado ao lado da imagem e as duas formas em preto e branco que sustentam a fotografia, como um fundo capaz de criar outros planos na página. Na fotografia destaca-se uma mulher com um vestido preto posando deitada em um sofá, tendo em uma de suas mãos um cigarro aceso. $\mathrm{O}$ que chama atenção é a manipulação feita na imagem para que se 


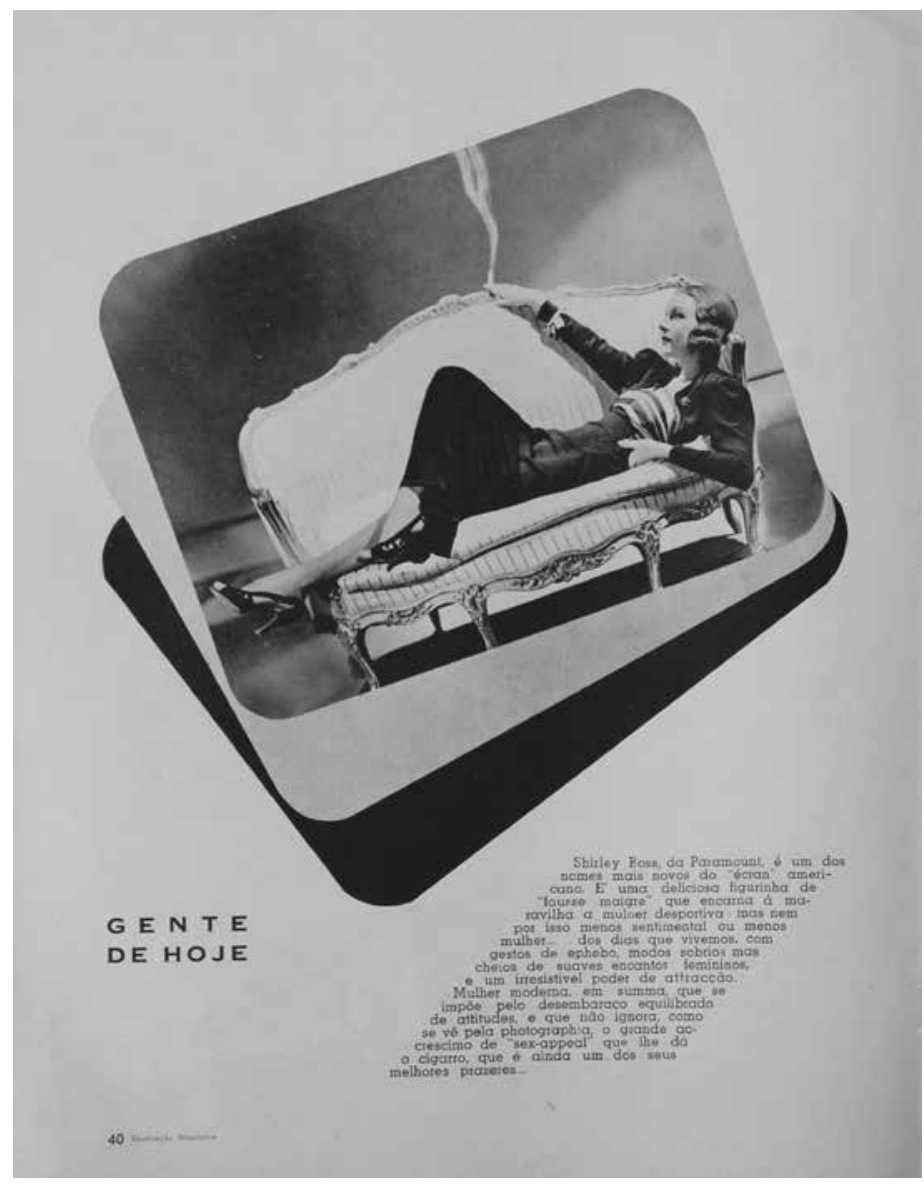

evidencie a fumaça saindo do cigarro, fumaça essa que atrai o olhar do espectador a ela.

O texto é iniciado revelando a identidade da mulher na fotografia, trata-se de Shirley Ross contratada pelo estúdio Paramount. Shirley Ross foi uma atriz americana de sucesso nas décadas de 1930 e 1940. A mesma é descrita no texto como

mulher moderna, em summa, que se impõe pelo desembaraço equilibrado de attitudes, e que não ignora, como se vê pela photografia, o grande acréscimo de "sex-appeal" que lhe dá o cigarro, que é ainda um dos seus melhores prazeres...(ILUSTRAÇÃO BRASILEIRA, 1939, p. 40).

Shirley Ross é caracterizada como uma mulher moderna e sensual em decorrência de suas atitudes. Atitudes essas que 
incluem o ato de fumar. As palavras presentes no texto que designam as atitudes da atriz revelam a tentativa de estabelecer, por meio das propagandas, padrões de comportamento aos leitores da revista. O cinema teve grande importância nesse sentido, por meio de recursos como filmes, mas também de propagandas, cartazes e da imprensa foram disseminados padrões estéticos e de comportamento.

O cinema hollywoodiano é articulador de comportamentos e constituidor de espectador, por emanações que partam exclusivamente dele, mas no uso que faz de temáticas e valores no seu próprio tempo. Os padrões de moral que os filmes apresentam, o padrão de beleza que as atrizes expressam, a exploração que a mídia faz da intimidade, discurso psicanalítico aplicado à fala dos filmes e de seus críticos, e que os críticos liam e o que se achava de cinema, todas estas falas funcionam enquanto produção de seu sujeito (MENEGUELLO, 1996, p. 69).

Nesse sentido, a teatralização dos gestos passa a ser muito importante para a constituição tanto dos personagens quanto dos próprios atores dentro e fora dos filmes. A divulgação feita pelos estúdios foi fator fundamental nesse processo, pois através de outros meios de comunicação foram disseminados hábitos, gestos e atitudes desses sujeitos.

O cigarro é um importante elemento dentro da construção da teatralização de gestos e atitudes no cinema. Ele passa a fazer parte da composição cênica dentro dos filmes e do seu gestual. Esses gestos e atitudes são transformados em elementos de distinção social. A propaganda comercial opera nesse sentido, ela associa o seu produto à imagem de pessoas invejáveis a fim de criar uma opinião positiva sobre o objeto. Segundo John Berger a propaganda não se refere ao presente, ela sempre fala do futuro, ela propõe que nos transformemos ao comprar um produto (BERGER, 1999, p.132-133).

A propaganda nos convence dessa transformação ao mostrar pessoas que aparentemente se transformaram e são, em vista disso, invejáveis. O estado de ser invejado é o que constitui o glamour. E a publicidade é o processo de fabricar o glamour (BERGER, 1999, p. 133).

A utilização de imagens de atrizes hollywoodianas nas propagandas de cigarro pela Ilustração Brasileira parece relevante nesse sentido. Ao mostrar mulheres bonitas, de sucesso e 
principalmente ao associar esses elementos ao uso do cigarro, a propaganda propõe ao consumidor que ele promova uma autotransformação. Apesar das atrizes serem distintas, e até representarem papéis totalmente diferentes nos filmes, elas apresentavam algo em comum: a imagem de elegância e sensualidade.

Assim, através dessas imagens, a propaganda insere no indivíduo uma insatisfação com sua condição atual sugerindo que, ao comprar o produto anunciado, ele terá sua imagem transformada.

\begin{abstract}
A propaganda "interpela" os indivíduos e convida-os a identificar-se com produtos, imagens, comportamentos. Apresenta uma imagem utópica de novidade, sedução, sucesso e prestígio mediante a compra de certos bens. Oferece magicamente uma autotransformação e uma nova identidade, associando as mudanças de comportamento, modo de vestir, aparência do consumidor com uma metamorfose em nova pessoa. Por conseguinte, os indivíduos aprendem a identificar-se com valores, modelos e comportamentos sociais através da propaganda, que é, portanto, um importante instrumento de socialização ao mesmo tempo determina a demanda do consumidor (KELLNER, 2001, p. 322).
\end{abstract}

Utilizando-se de imagens de atrizes famosas nas décadas de 1930 e 1940, imagens que incitam sensualidade e glamour e de textos que associam essas mulheres, seus gestos e atitudes ao que há de mais belo e moderno a revista Ilustração Brasileira, através de suas propagandas de cigarro, transformou o ato de fumar em uma experiência estética. Estética essa que podia ser consumida tanto por mulheres, ao pensar na transformação pessoal exercida ao consumir o cigarro, quanto por homens que poderiam consumir imagens que incitavam sensualidade e beleza.

Segundo Vestegaard e Schroder (2004, p. 12) a propaganda contribui não só para que os produtos pareçam esteticamente agradáveis, o próprio anúncio se converte em uma realização estética, e nesse transcurso o consumidor sofre também um processo de estetização.

\title{
Considerações finais
}

A propaganda comercial pode aparecer dentro dos impressos de várias formas e uma delas é a propaganda indireta. Na Ilustração Brasileira entre 1937 e 1945, essa foi a principal estratégia utilizada para propagar o consumo dos cigarros industrializados. Essas propagandas eram integradas à 
revista de forma que se assemelhasse ao conjunto da mesma, produzidas dentro de seu projeto gráfico.

Considerando os principais elementos utilizados para compor a página e como foram integrados a ela para produzirem sentidos quando lidos/vistos pelos leitores da revista, podemos refletir que por meio da utilização de imagens de atrizes hollywoodianas, a revista transforma o ato de fumar em uma experiência estética marcada por gestos e atitudes que conferiam elegância, glamour e sensualidade às mulheres. Estética que é possível ser adquirida após o consumo do cigarro. Sendo assim, a propaganda utiliza a ideia de autotransformação do indivíduo ao consumir o produto e, para estimular a necessidade de transformação no indivíduo, utiliza imagens de pessoas de sucesso.

\section{Referências}

AUMONT, Jacques. A imagem. Campinas: Papirus, 1993.

BARTHES, Roland. O óbvio e o obtuso. Lisboa: Edições 70, 2009.

BENJAMIN, Walter. A obra de arte na era de sua reprodutibilidade técnica. In: BENJAMIN, Walter [et al.]. Benjamin e a obra de arte: técnica, imagem, percepção. Rio de Janeiro: Contraponto, 2012.

BERGER, John. Modos de ver. Rio de Janeiro: Rocco, 1999.

CALIL, Carlos Augusto. Cinema e indústria. In: XAVIER, Ismail. O cinema no século. Rio de Janeiro: Imago, 1996.

CARNEIRO, Marlón de Oliveira Borges. O projeto gráfico da revista Ilustração Brasileira: um objeto moderno? Monografia (graduação em História)- INHIS- UFU, Uberlândia, 2010.

COSTA, Flávia Cesarino. Primeiro Cinema. In: MASCARELLO, Fernando (Org.). História do cinema mundial. Campinas: Papirus, 2012.

DEL PRIORE, Mary. Corpo a corpo com a mulher: pequena história das transformações do corpo feminino. São Paulo: Editora Senac São Paulo, 2000.

DUTRA, Eliana de Freitas. Cultura. In: GOMES, Angela de Castro (Coord.). Olhando para dentro: 1930-1964. Rio de Janeiro: Objetiva, 2013.

ILUSTRAÇÃO BRASILEIRA, Rio de Janeiro, ano XV, n. 32, dez. 1937, p. 51.

ILUSTRAÇÃO BRASILEIRA, Rio de Janeiro, ano XVI, n.39, jul. 1938, p. 40.

ILUSTRAÇÃO BRASILEIRA, Rio de Janeiro, ano XVII, n. 45, Jan. 1939, p. 41. 
ILUSTRAÇÃO BRASILEIRA, Rio de Janeiro, ano XVII, n.46, fev. 1939, p. 40.

KELLNER, Douglas. A cultura da Mídia - estudos culturais: identidade e política entre o moderno e o pós-moderno. Bauru: EDUSC, 2001.

KLEIN, Richard. Cigarros são sublimes: uma história cultural de estilo e fumaça. Rio de Janeiro: Rocco, 1997.

KOSSOY, Boris. Fotografia e História. São Paulo: Ateliê Editorial, 2001.

LEHMKUHL, Luciene. Fazer história com imagens. In: PARANHOS, Kátia; LEHMKUHL, Luciene; PARANHOS, Adalberto. (Org.). História e imagens: textos visuais e práticas de leituras. Campinas: Mercado de Letras, 2010.

LUCA, Tânia Regina de. História dos, nos e por meio dos periódicos. In: PINSKY, Carla Bassanezi (Org.). Fontes Históricas. São Paulo: Contexto, 2008.

MENEGUELlO, Cristina. Poeira das estrelas: O cinema Hollywoodiano na mídia brasileira das décadas de 40 e 50. Campinas: Editora da Unicamp, 1996.

MORIN, Edgar. As estrelas: mito e sedução no cinema. Rio de Janeiro: José Olympio, 1989.

MULVEY, Laura. Cinema e sexualidade. In: XAVIER, Ismail. O cinema no século. Rio de Janeiro: Imago, 1996.

VESTERGAARD, Torben; SCHRODER, Kim. A linguagem da propaganda. São Paulo: Martins Fontes, 2004.

Recebido em: 30/03/14

Aceito em: 09/07/14

\section{LARA LOPES}

lara_lilith@yahoo.com.br

Doutoranda em História Social pelo Programa de Pós-Graduação em História da Universidade Federal de Uberlândia com ênfase em História e Cultura. Seus interesses em pesquisa estão focados nos Estudos da Imagem, imprensa, propaganda e cinema. 